\section{Pacific Northwest}

National Laboratory

Operated by Battelle for the

U.S. Department of Energy

\title{
GridLAB-D Technical Support Document: Climate Module Version 1.0
}

ND Tenney

May 2008

Prepared for the U.S. Department of Energy under Contract DE-AC05-76RL01830

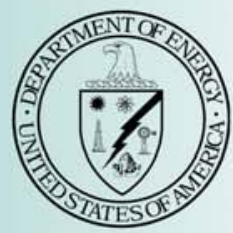




\title{
DISCLAIMER
}

This report was prepared as an account of work sponsored by an agency of the United States Government. Neither the United States Government nor any agency thereof, nor Battelle Memorial Institute, nor any of their employees, makes any warranty, express or implied, or assumes any legal liability or responsibility for the accuracy, completeness, or usefulness of any information, apparatus, product, or process disclosed, or represents that its use would not infringe privately owned rights. Reference herein to any specific commercial product, process, or service by trade name, trademark, manufacturer, or otherwise does not necessarily constitute or imply its endorsement, recommendation, or favoring by the United States Government or any agency thereof, or Battelle Memorial Institute. The views and opinions of authors expressed herein do not necessarily state or reflect those of the United States Government or any agency thereof.

\author{
PACIFIC NORTHWEST NATIONAL LABORATORY \\ operated by \\ BATTELLE \\ for the \\ UNITED STATES DEPARTMENT OF ENERGY \\ under Contract DE-AC05-76RL01830
}

Printed in the United States of America
Available to DOE and DOE contractors from the Office of Scientific and Technical Information,
P.O. Box 62, Oak Ridge, TN 37831-0062;
ph: (865) 576-8401
fax: (865) 576-5728
email: reports@adonis.osti.gov

\begin{abstract}
Available to the public from the National Technical Information Service, U.S. Department of Commerce, 5285 Port Royal Rd., Springfield, VA 22161 ph: (800) 553-6847 fax: (703) 605-6900 email: orders@ntis.fedworld.gov online ordering: http://www.ntis.gov/ordering.htm
\end{abstract}




\section{GridLAB-D Technical Support Document: Climate Module Version 1.0}

ND Tenney

May 2008

Prepared for

the U.S. Department of Energy

under Contract DE-AC05-76RL01830

Pacific Northwest National Laboratory

Richland, Washington 99352 



\section{Acronyms and Abbreviations}

NREL

National Renewable Energy Laboratory

TMY

typical meteorological year 


\section{Contents}

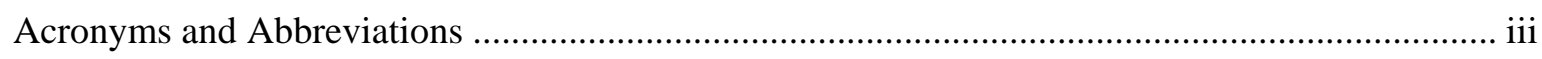

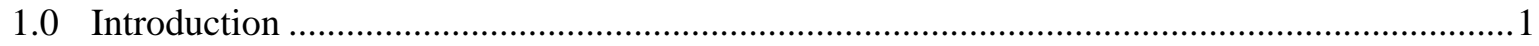

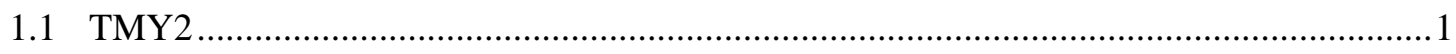

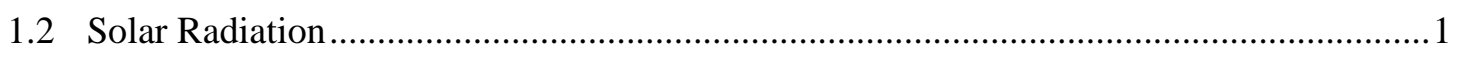

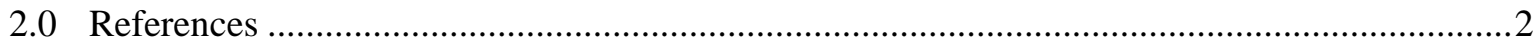




\subsection{Introduction}

The climate module provides an interface that other objects may use to include weather data in their calculations. Objects such as houses and buildings rely on this data to factor outdoor weather into their calculations for internal temperature. The climate data includes temperature, humidity, and solar radiation, which is used to calculate temperature gain that is the result of heat gained from direct exposure of a surface to sunlight. The Climate Module Version 1.0 retrieves climate data from TMY2 files, created and maintained by the National Renewable Energy Laboratory (NREL).

\subsection{TMY2}

TMY is an acronym for typical meteorological year. In a TMY file, weather data for a particular location is aggregated and averaged to provide a typical baseline for the weather of a particular geographical location on a given day at a given hour. TMY data is not suitable for modeling extreme situations and is not necessarily a good indicator for forecasting, but it is an indication of typical weather conditions over an extended period of time. The TMY2 format is an extension of the original TMY format to include information necessary for solar radiation calculations.

\subsection{Solar Radiation}

In the climate module, calculations are performed for solar radiation on a surface facing each of the eight major compass points (N, S, E, W, NE, NW, SE, SW) and a horizontal surface. For each surface, the total incident solar radiation is calculated by the following equation:

$$
\mathrm{RAD}_{\text {SOLAR }}=\mathrm{RAD}_{\text {DIRECT }} * \cos \left(\mathrm{ANGLE}_{\text {INCIDENT }}\right)+\mathrm{RAD}_{\text {DIFFUSE }}
$$

where

$\mathrm{RAD}_{\text {DIRECT }}=$ the direct normal radiation for time and day

$\mathrm{RAD}_{\text {DIFFUSE }}=$ the diffuse horizontal radiation.

$\mathrm{ANGLE}_{\text {INCIDENT }}=$ the angle of the sun relative to the surface (assuming the surface to be perpendicular to the Earth at that point, excepting the horizontal surface).

The incident angle is calculated by first calculating the solar time, which takes into account the Earth's wobble through the year. The solar time is combined with the latitude of the surface, the slope of the surface relative to the horizontal $\left(90^{\circ}\right.$ for all surfaces except the horizontal surface), and the azimuth angle relative to south (+ east of south, - west of south), and the day of the year (which is used in a calculation of the solar declination angle) to produce the cosine of the indent angle as follows.

$$
\begin{gathered}
\text { Decl }_{\text {solar }}=0.409280 * \sin \left(2.0 * \pi * \frac{(284+\text { day_of_year })}{365}\right) \\
\text { angle }_{\text {hour }}=-\left(15.0 * \frac{\pi}{180}\right) *(\text { solar_time }-12.0)
\end{gathered}
$$




$$
\begin{aligned}
& \cos \left(\text { ANGLE } E_{\text {INCIDENT }}\right)=\sin (\text { Declsolar }) * \sin (\text { latitude }) * \cos (\text { slope }) \\
& -\sin \left(\text { Decl }_{\text {solar }}\right) * \cos (\text { latitude }) * \sin (\text { slope }) * \cos (\text { azimuth }) \\
& +\cos (\text { Declsolar }) * \cos (\text { latitude }) * \cos (\text { slope }) * \cos (\text { angle } \text { hour }) \\
& +\cos (\text { Declsolar }) * \sin (\text { latitude }) * \sin (\text { slope }) * \cos (\text { azimuth }) * \cos (\text { angle hour }) \\
& +\cos (\text { Declsolar } * \sin (\text { slope }) * \sin (\text { azimuth }) * \sin (\text { anglehour })
\end{aligned}
$$

Leap years are handled by the fact that an hour of year calculation on February 29 would result in the

same hour of year as March 1 on a normal year. March 1 would be used twice in a simulation involving a leap year.

\subsection{References}

John A Duffie and William A Beckman, "Solar Energy Thermal Processes," John Wiley \& Sons, 1974 